Supplement of Saf. Nucl. Waste Disposal, 1, 51-52, 2021

https://doi.org/10.5194/sand-1-51-2021-supplement

(C) Author(s) 2021. CC BY 4.0 License.

Supplement of

\title{
Site selection for the best clay-hosted repository in Switzerland
}

Tim Vietor and Michael Schnellmann

Correspondence to: Tim Vietor (tim.vietor@ nagra.ch)

The copyright of individual parts of the supplement might differ from the article licence. 


\section{Site selection for the best clay- hosted repository in Switzerland}

Tim Vietor and Michael Schnellmann

National Cooperative for the Management of Radioactive Waste 
Swiss storage for 12.400 fuel elements and 600 pcs of vitrified waste
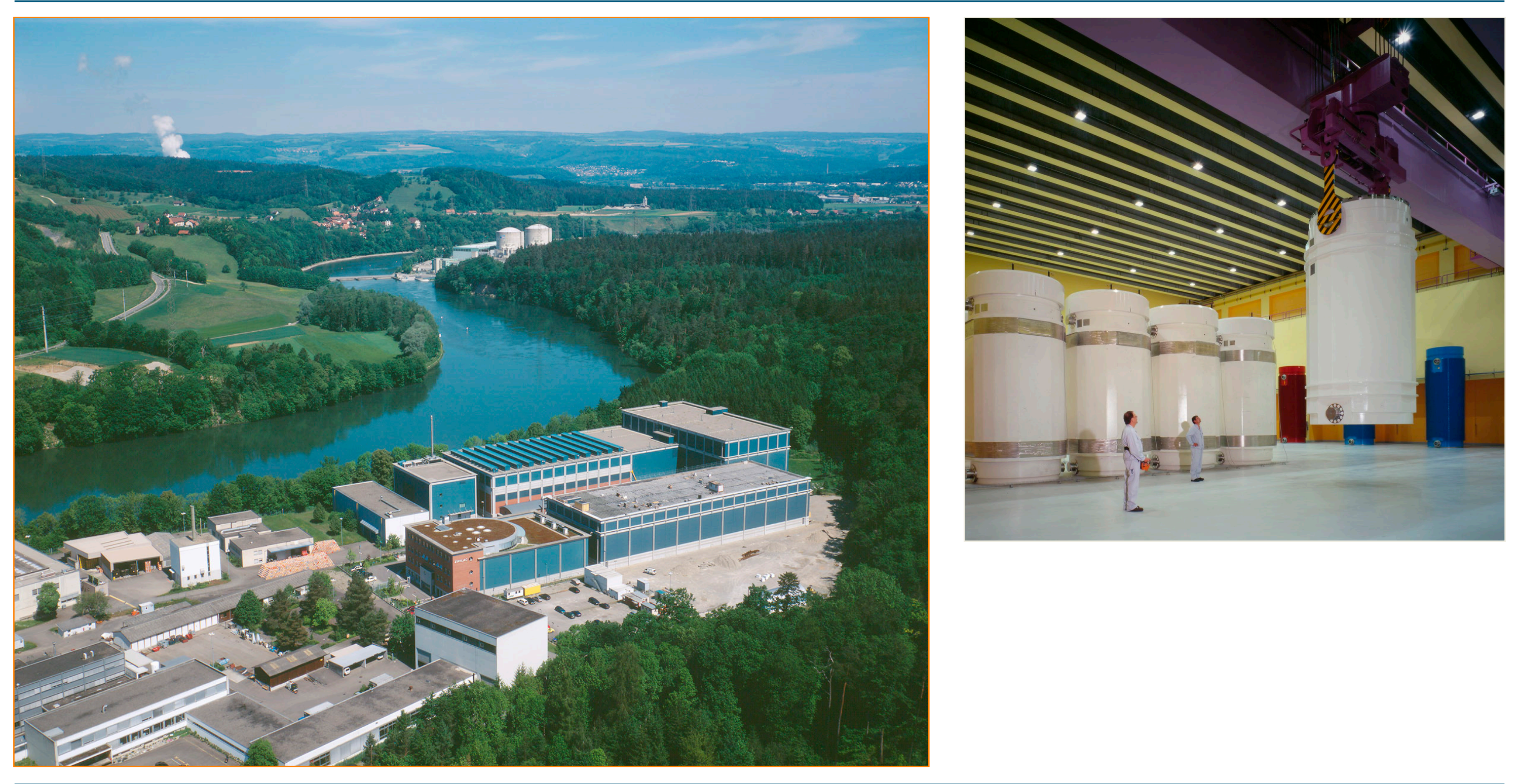


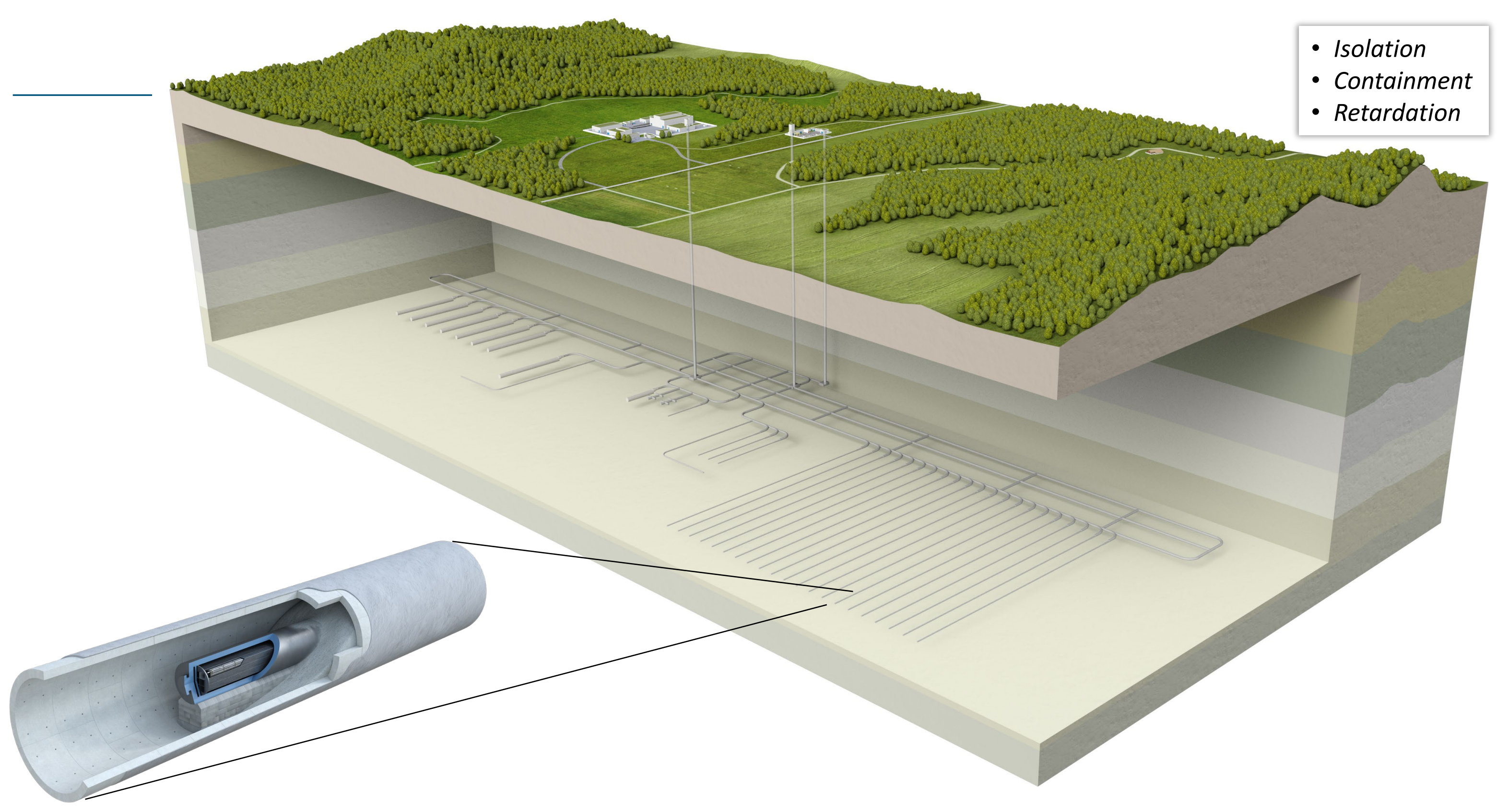


White map to site: 2008 re-start of process

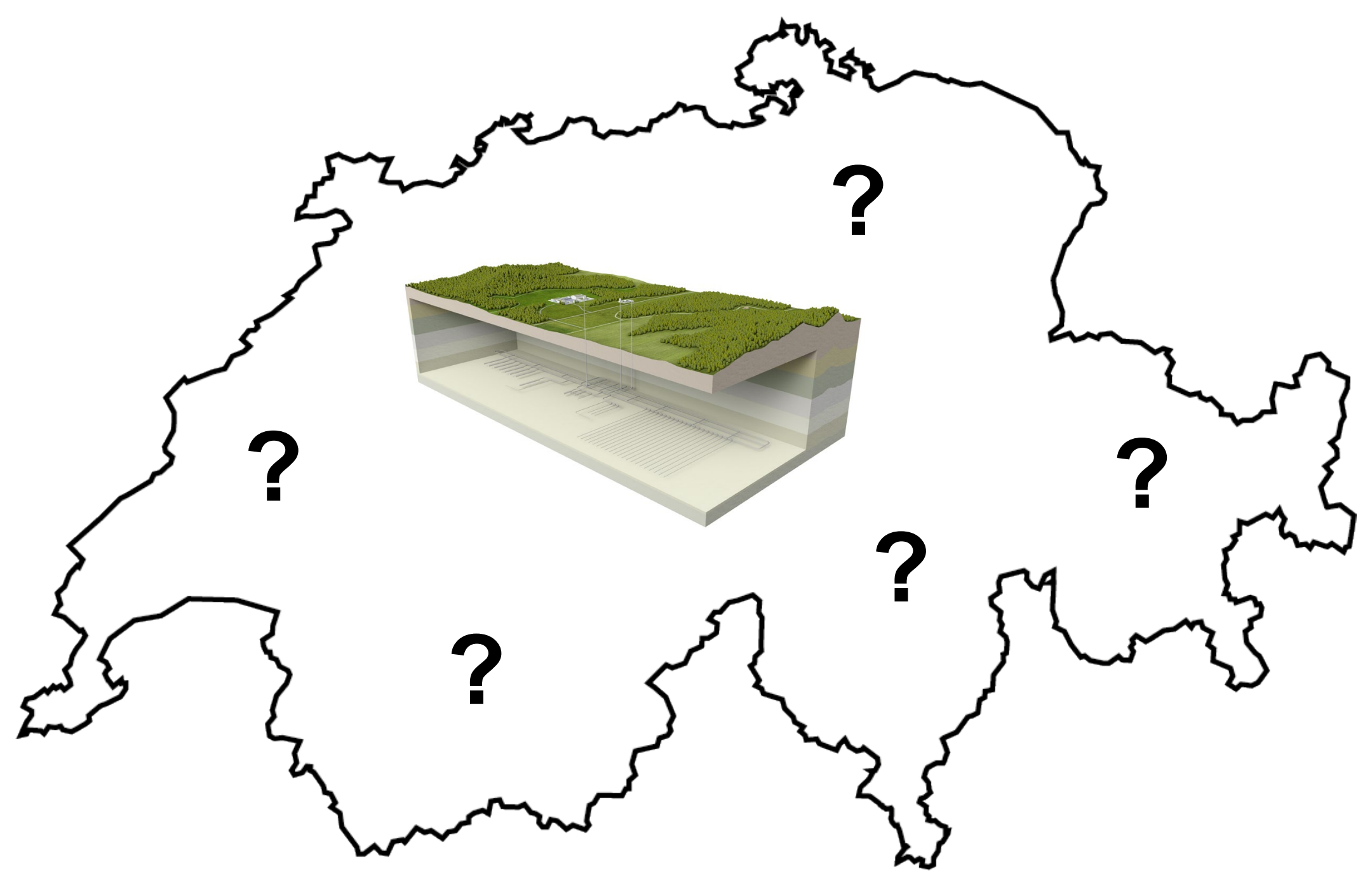




\section{Criteria for site evaluation: safety and technical feasibility}

- 13 criteria in 4 groups

- For all steps of the siteselection process

- No cut-off values

- Application per step to be proposed by implementer

\begin{tabular}{|l|l|l}
\hline Criteria group & Criteria \\
\hline $\begin{array}{l}1.1 \text { Spatial extent } \\
1.2 \text { Hydraulic barrier effect } \\
\text { containment zone }\end{array}$ & $\begin{array}{l}1.3 \text { Geochemical conditions } \\
1.4 \text { Release pathways }\end{array}$ \\
\hline 2. Long-term stability & $\begin{array}{l}2.1 \text { Stability of the site and rock properties } \\
2.2 \text { Erosion }\end{array}$ \\
& $\begin{array}{l}2.3 \text { Repository-induced influences } \\
2.4 \text { Conflicts of use }\end{array}$ \\
\hline 3. Reliability of geological findings & $\begin{array}{l}3.1 \text { Ease of characterisation of the rock } \\
3.2 \text { Explorability of spatial conditions } \\
\end{array}$ \\
\hline 4. Engineering suitability & $\begin{array}{l}3.3 \text { Predictability of long-term changes } \\
4.1 \text { Rock mechanical properties and conditions }\end{array}$ \\
\hline
\end{tabular}

BFE 2008 


\section{Nationwide Stepwise Screening HLW Example: steps 1 and 2}

2008 «White Map of Switzerland»

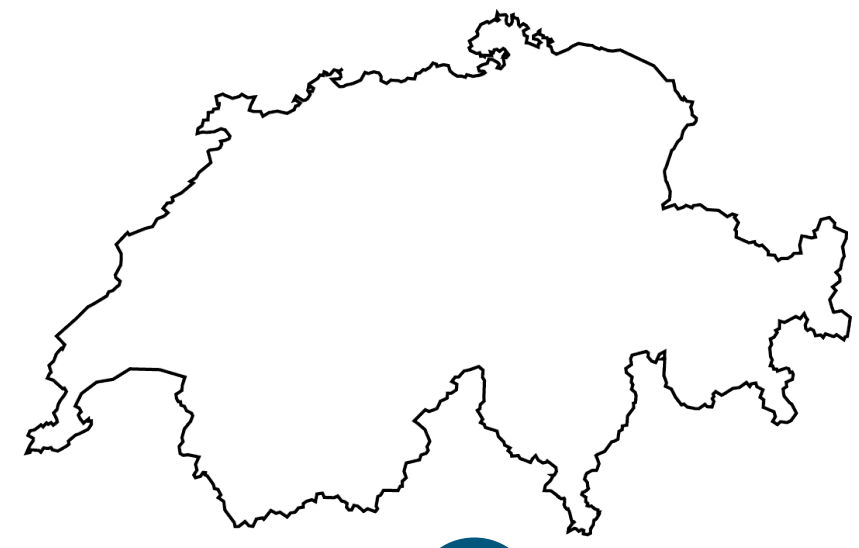

$\oplus$

GEODYNAMICS
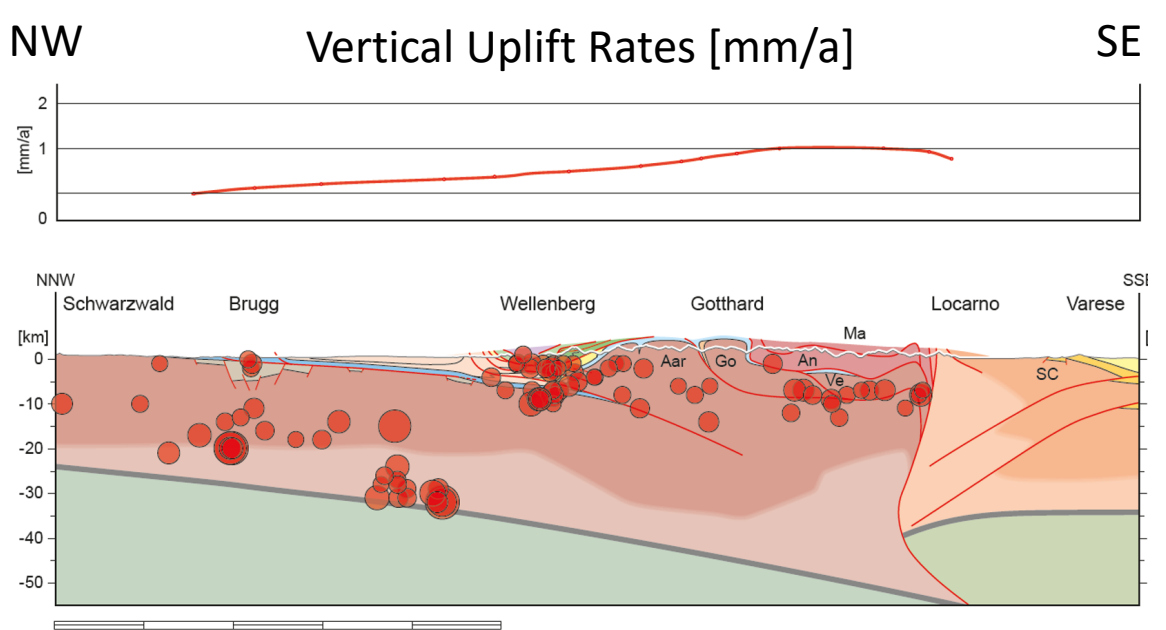

$100 \mathrm{~km}$
Suitable Geotectonic Units

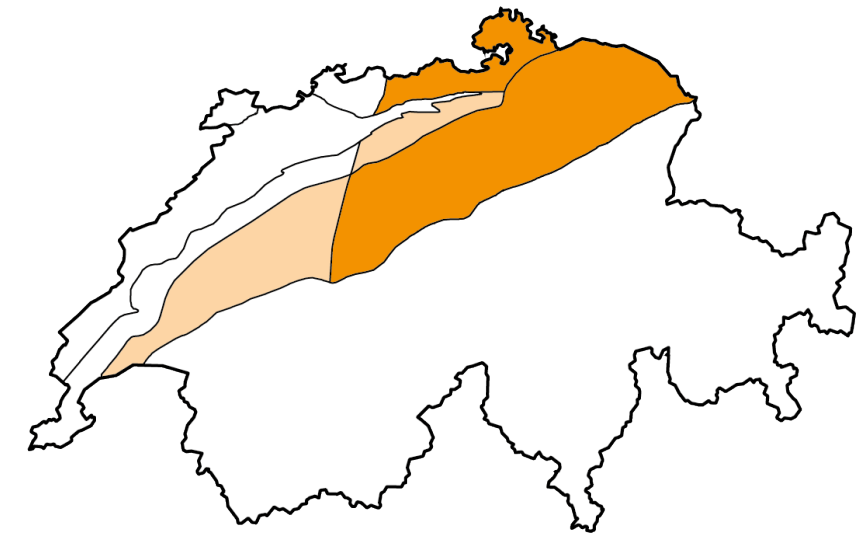

$\oplus$

HOST ROCK DISTRIBUTION

(Depth, Thickness)

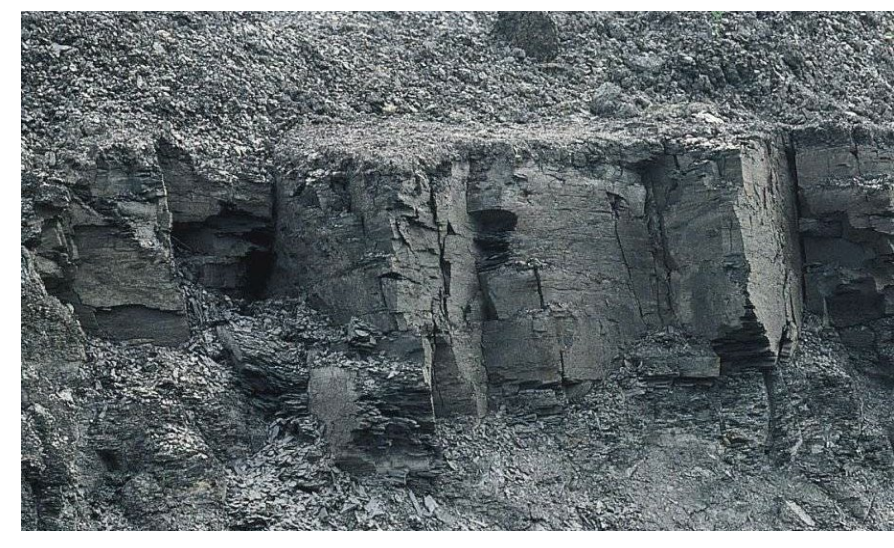

Hostrock Configurations

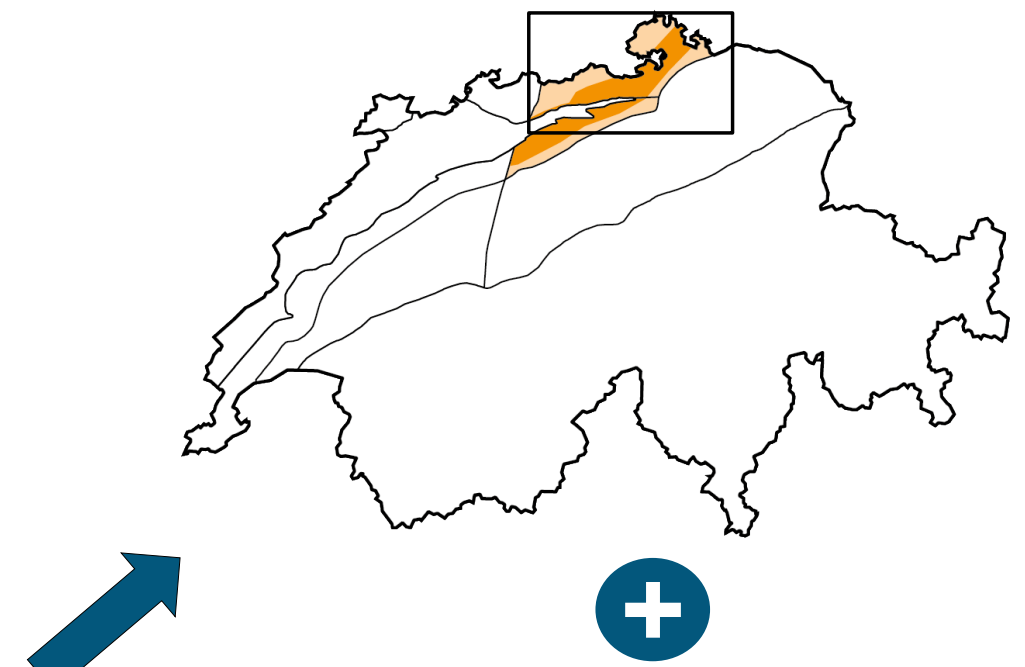

STRUCTURAL FRAMEWORK

(Regional Fault Zones...)

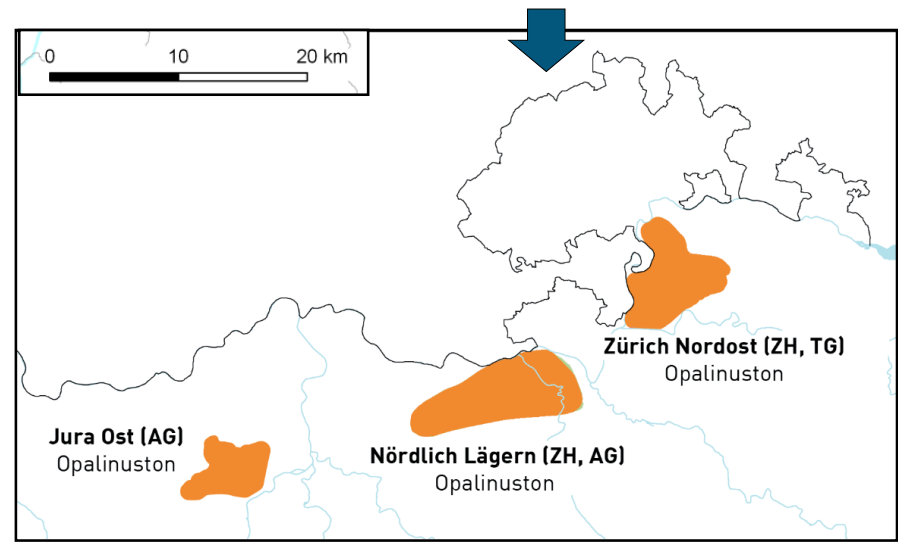

Announcement of site(s): fall 2022 
Clay rocks: Low permeability at high clay content

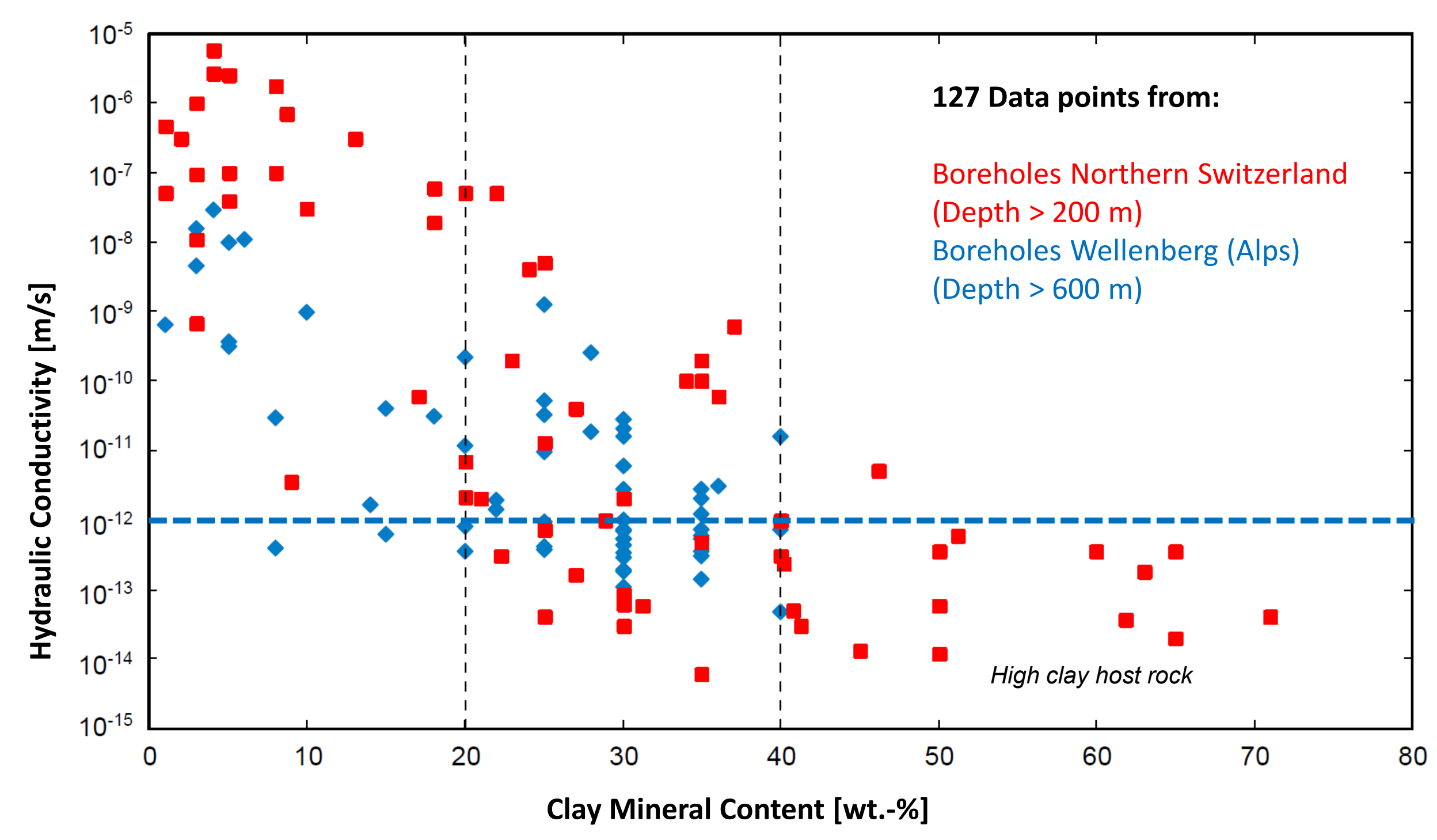




\section{Clays in marine succession: explorable by seismic methods}

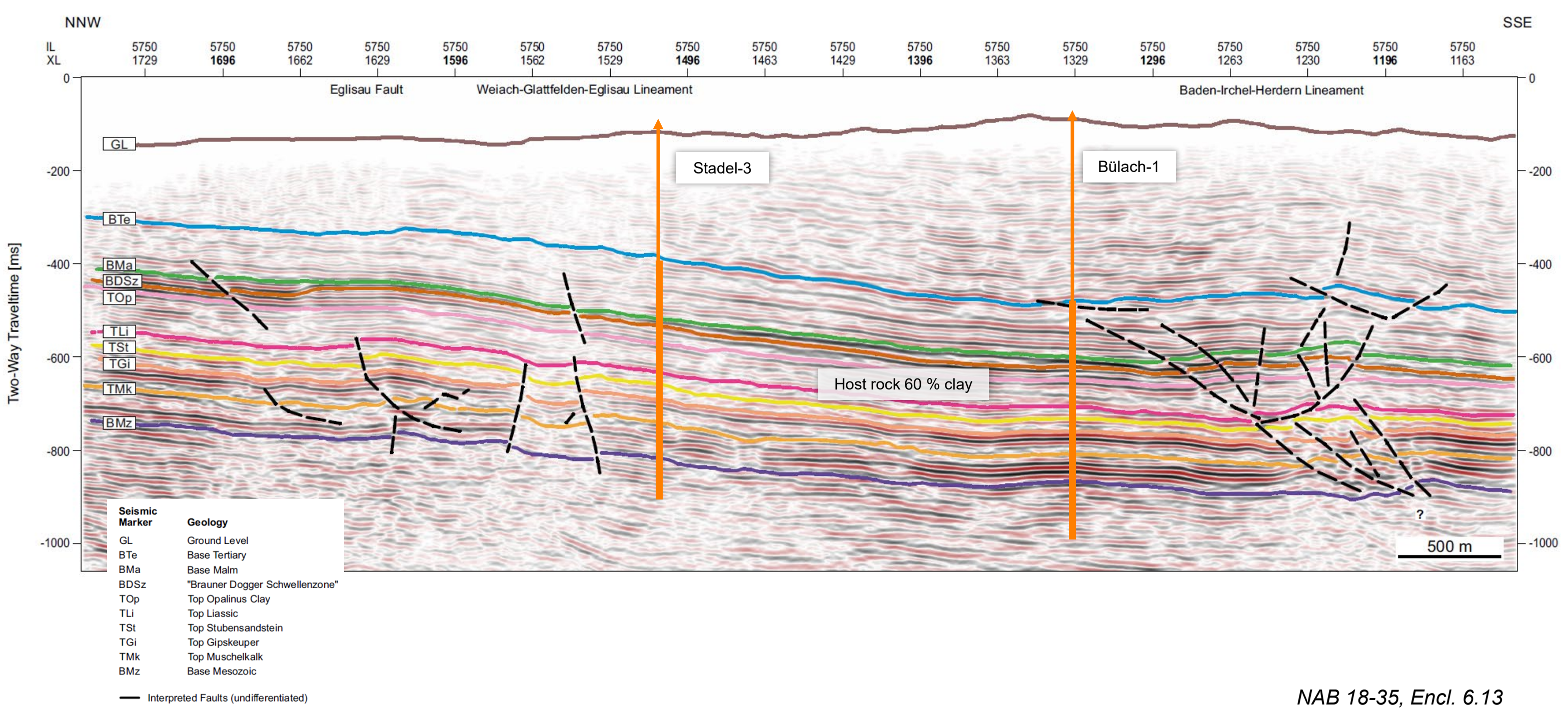

NAB 18-35, Encl. 6.13 


\section{D Seismics: spatial extent of tectonically quiet zones (crit. 2.1)}

Red lines: Faults based on amplitude picking

Blue Lines: indications for minor faults on attribute maps
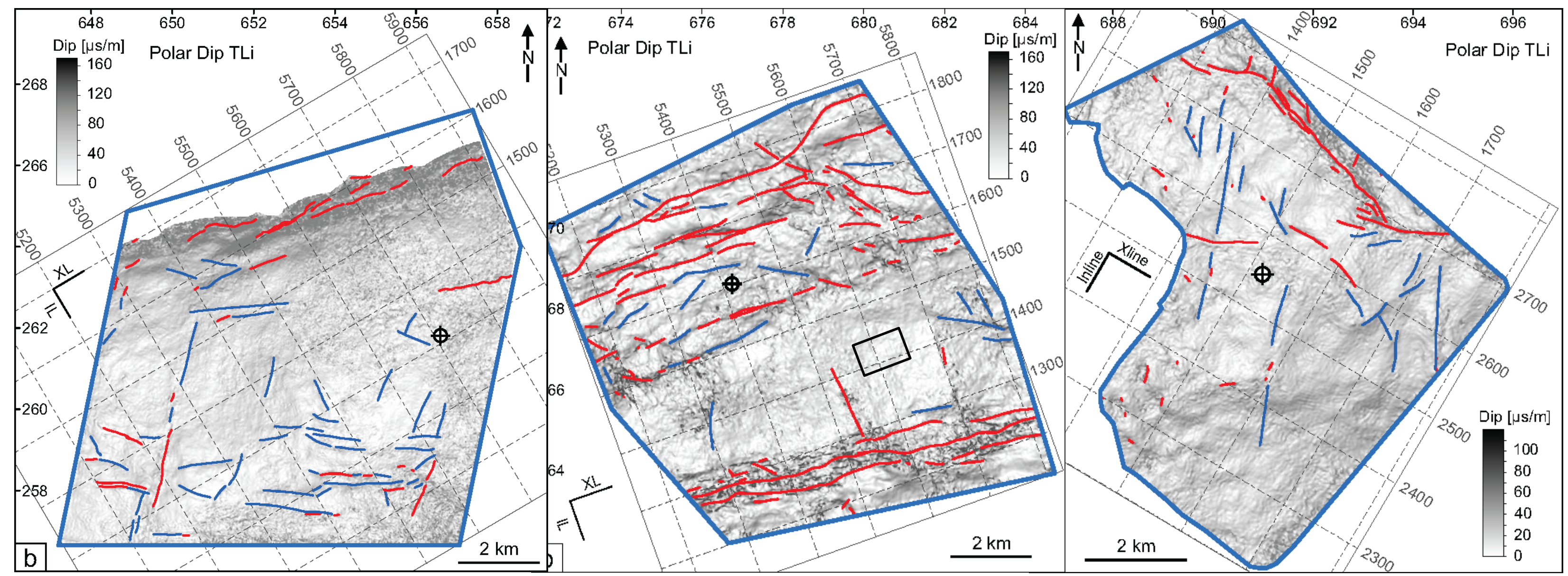


\section{Surface based investigation: Integration of 3D-seismics and boreholes}

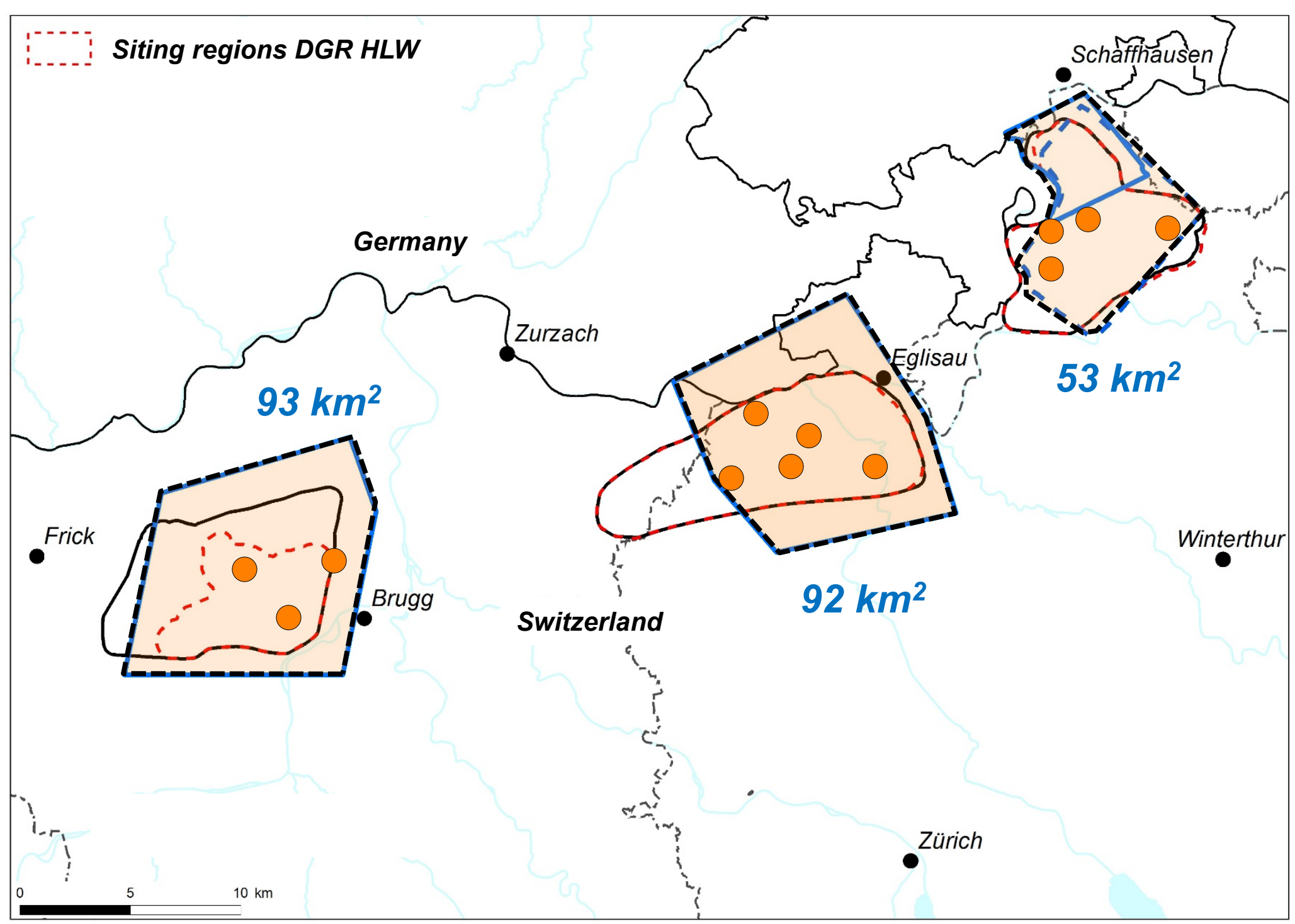


- 9 boreholes 829 to $1370 \mathrm{~m}$

- $5300 \mathrm{~m}$ of core 90 packertests - 33 in host formation

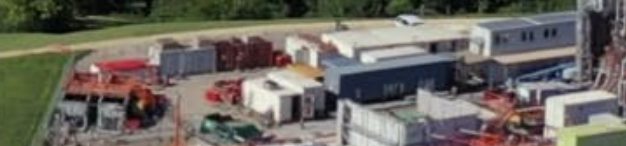


Drill site to decision base: ensure reliable, reproducible data
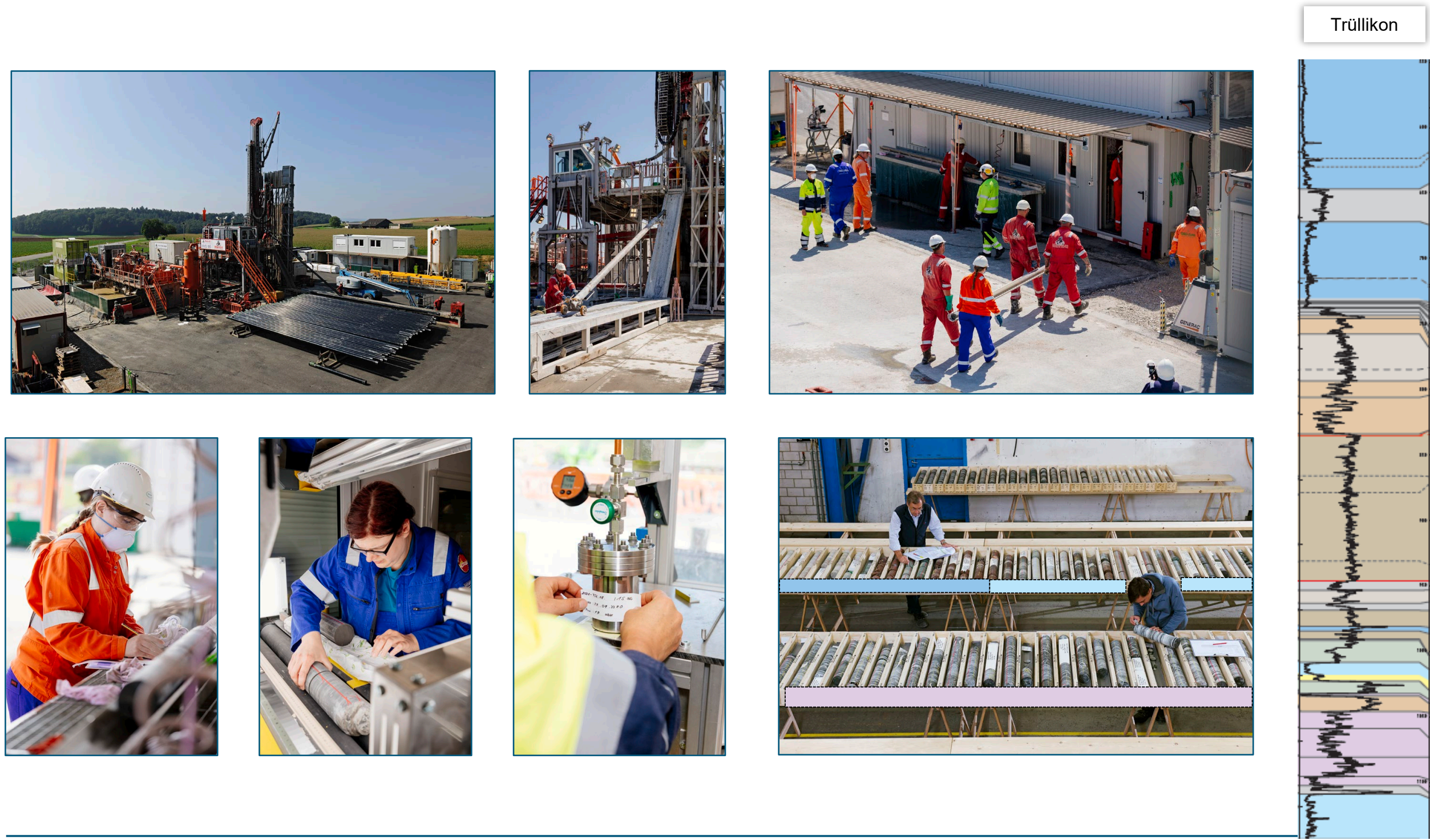
Cored boreholes for comparison of natural barrier layers

Host rock thickness with low variation; differences in surrounding aquitard sequence

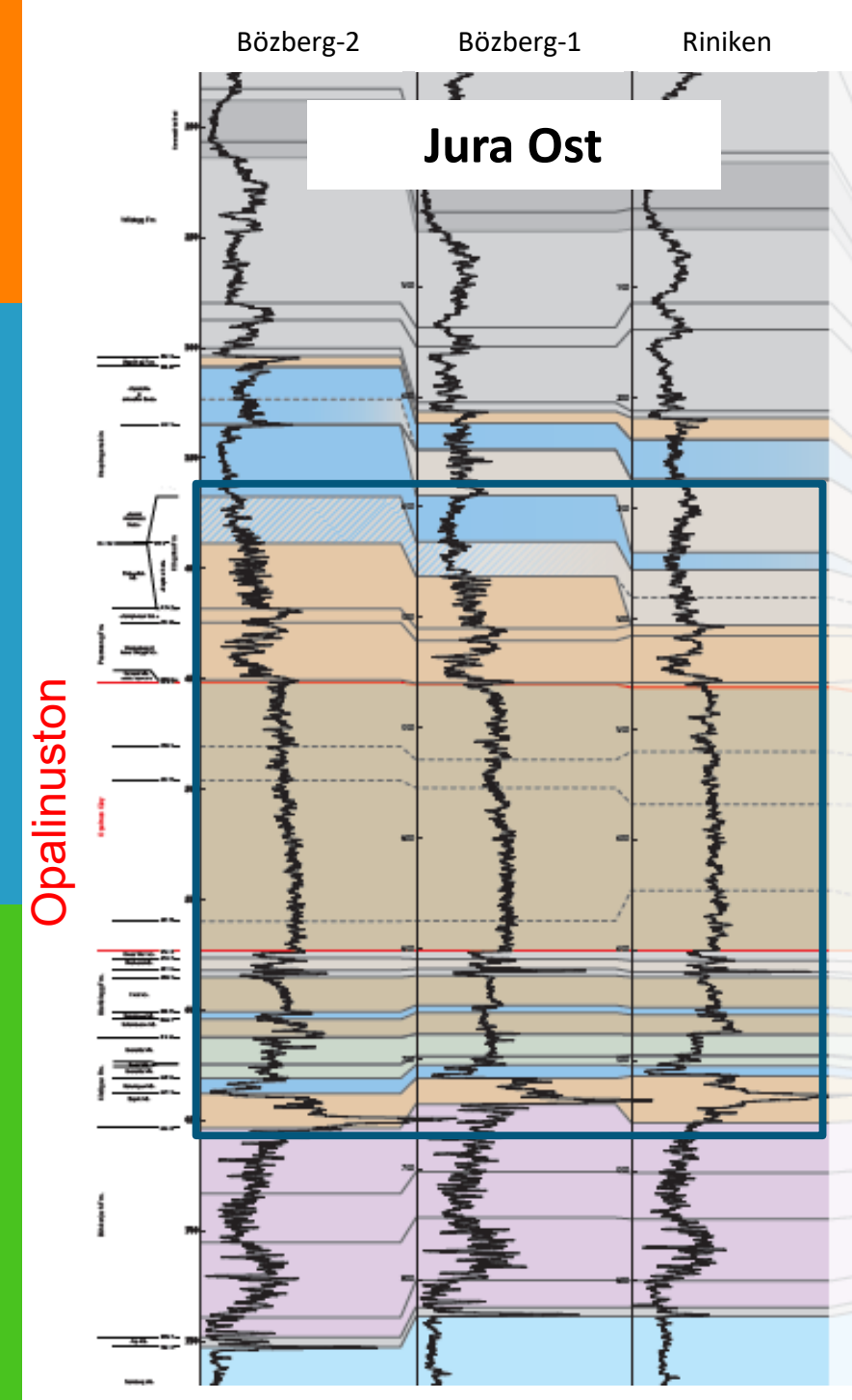

Nagra - field data under review

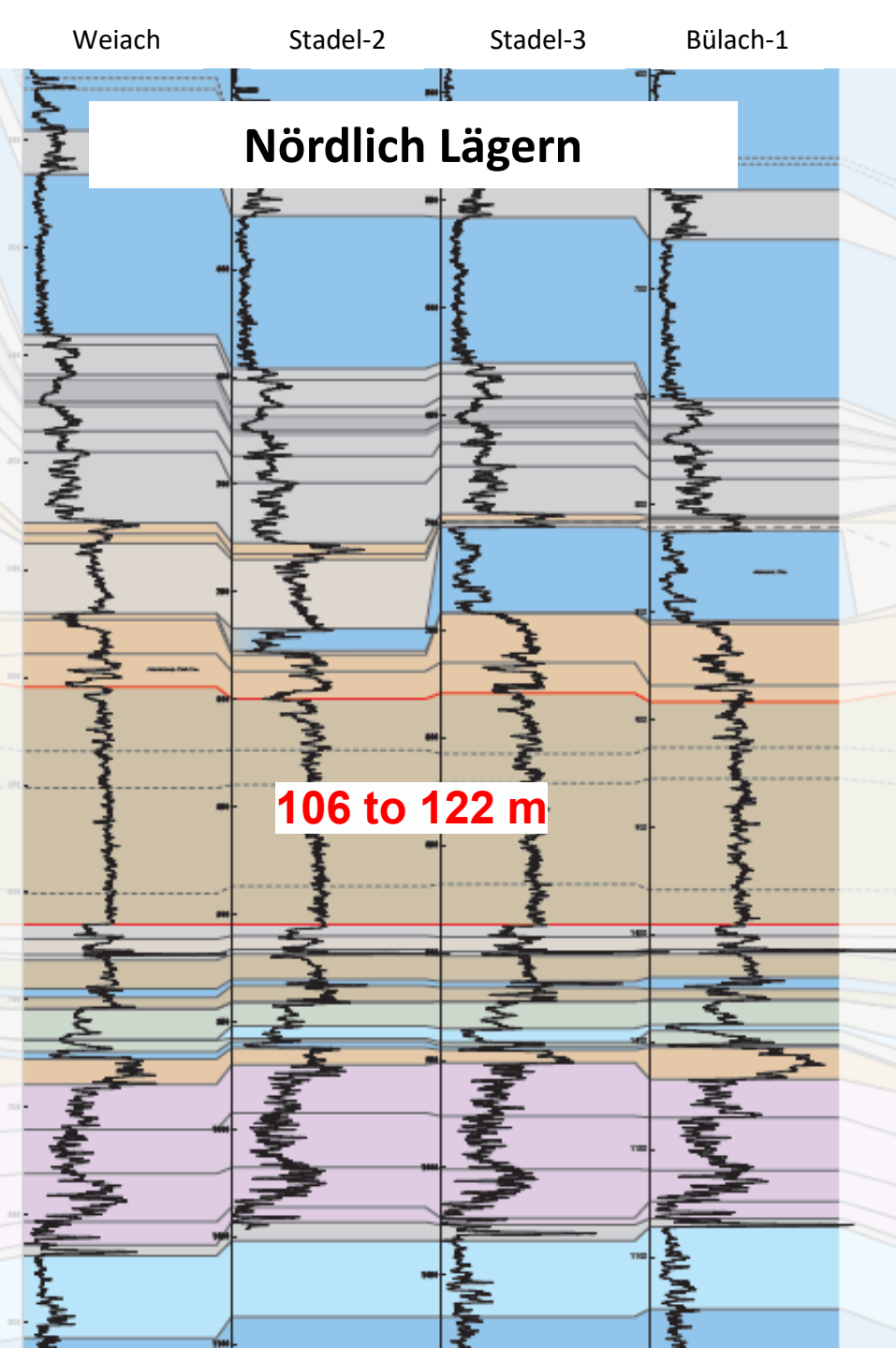

Vietor SafeND Berlin 2021

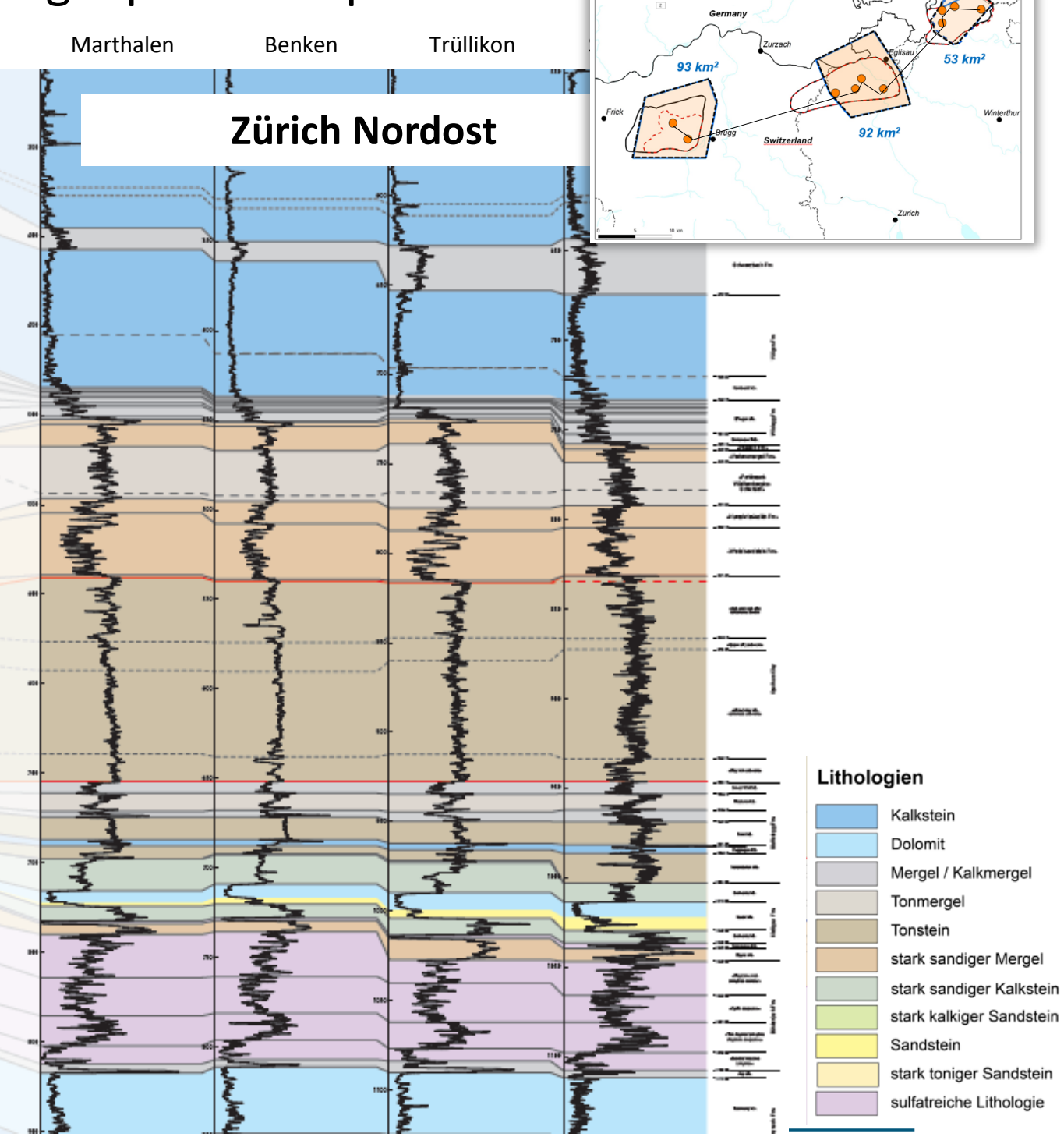

nagra 


\section{Drilling results}

Opalinus Clay

- Stable climate conditions $\rightarrow$ uniform sediments

- High sedimentation rate (10'000 years / $1 \mathrm{~m}$, confining units up to 1 Mio years / $1 \mathrm{~m})$

- Highly correlatable $\rightarrow 10$ s of kms very similar

- Little tectonics $\rightarrow$ uniform thickness

For the DGR

- Average clay content $60 \%$

- Very low hydraulic conductivity (1e-12 m/s or less)

- Reliably self-sealing

- Very low uncertainties

- $\rightarrow$ backbone of safety case

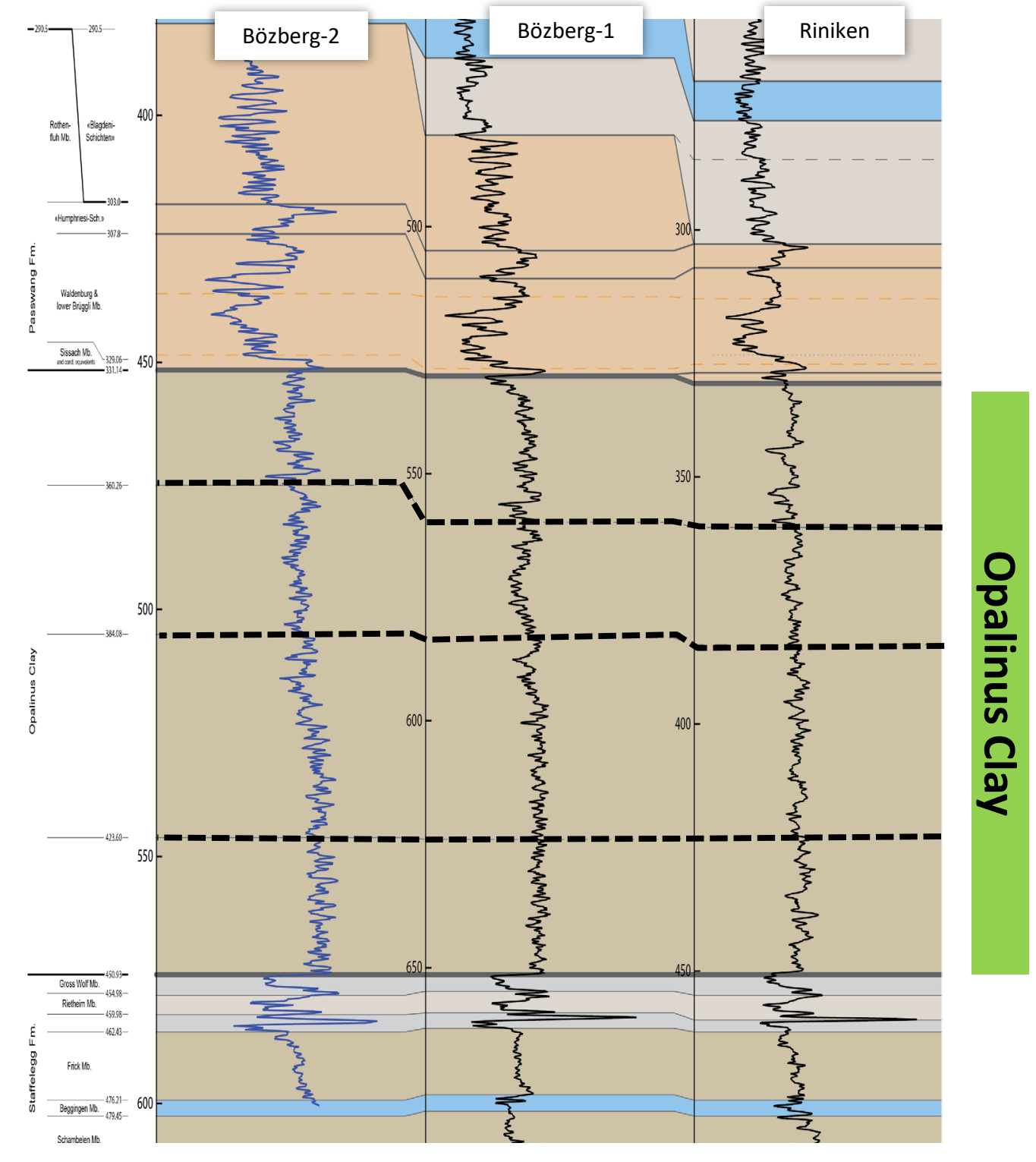


- Diffusion properties (plus sorption) govern transport of waste products

- Lab work on rock samples lead to diffusion coefficients

- Diffusion data fit geological history

- Excellent system understanding

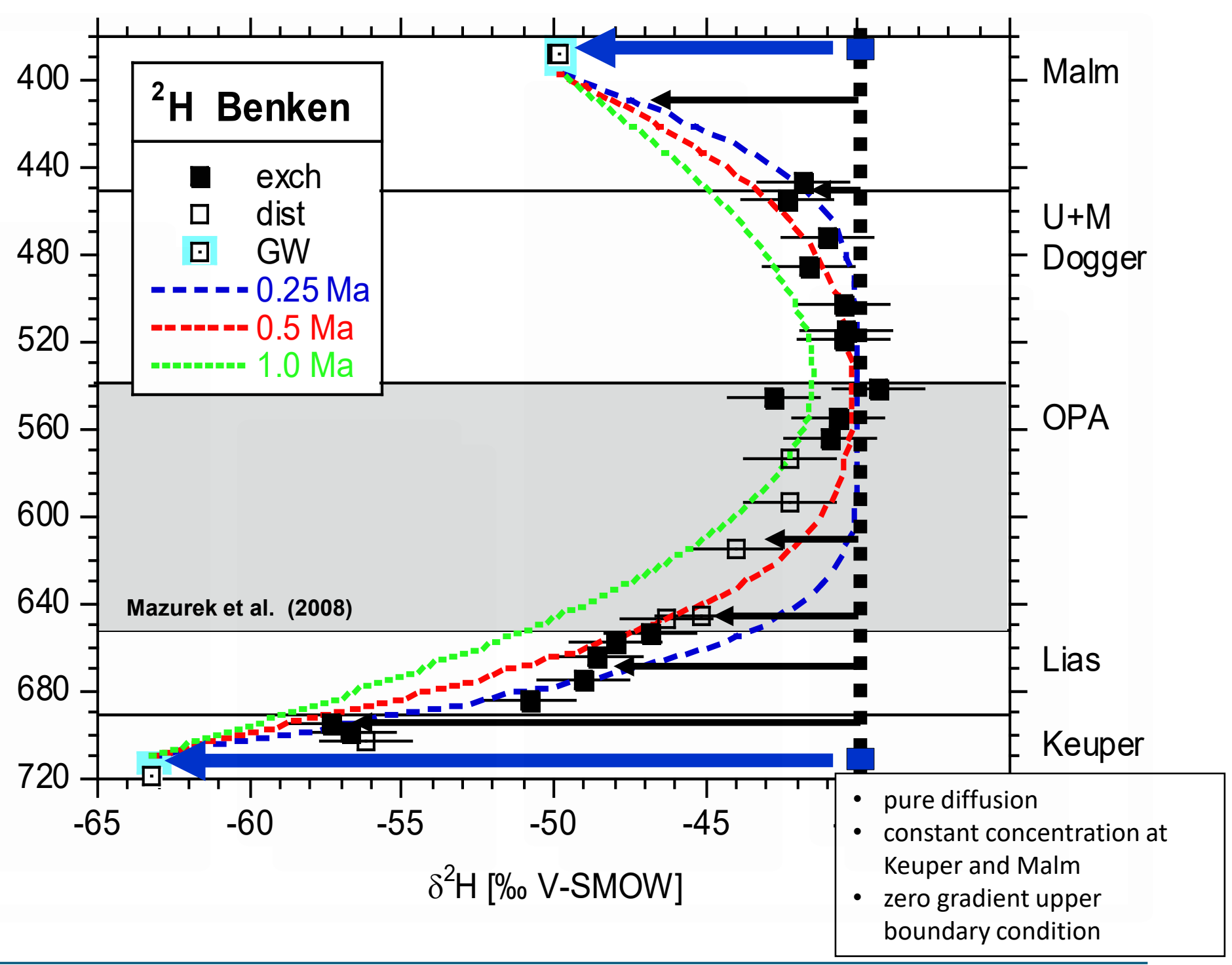




\section{Profiles $\delta^{2} \mathrm{H}$}
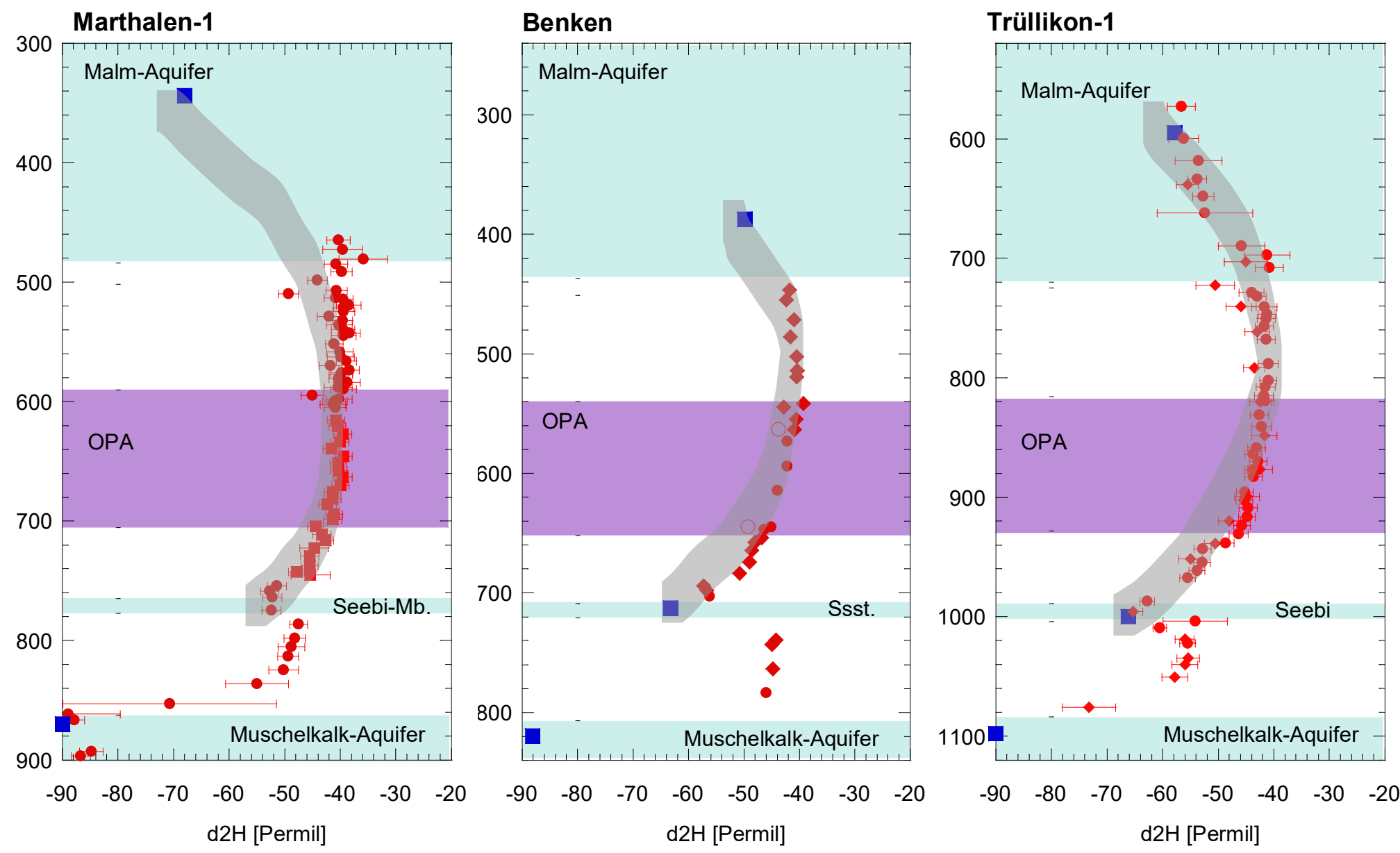

Porenwasser

Grundwasser 


\section{Host rock and confining units lessons from dose calculations}

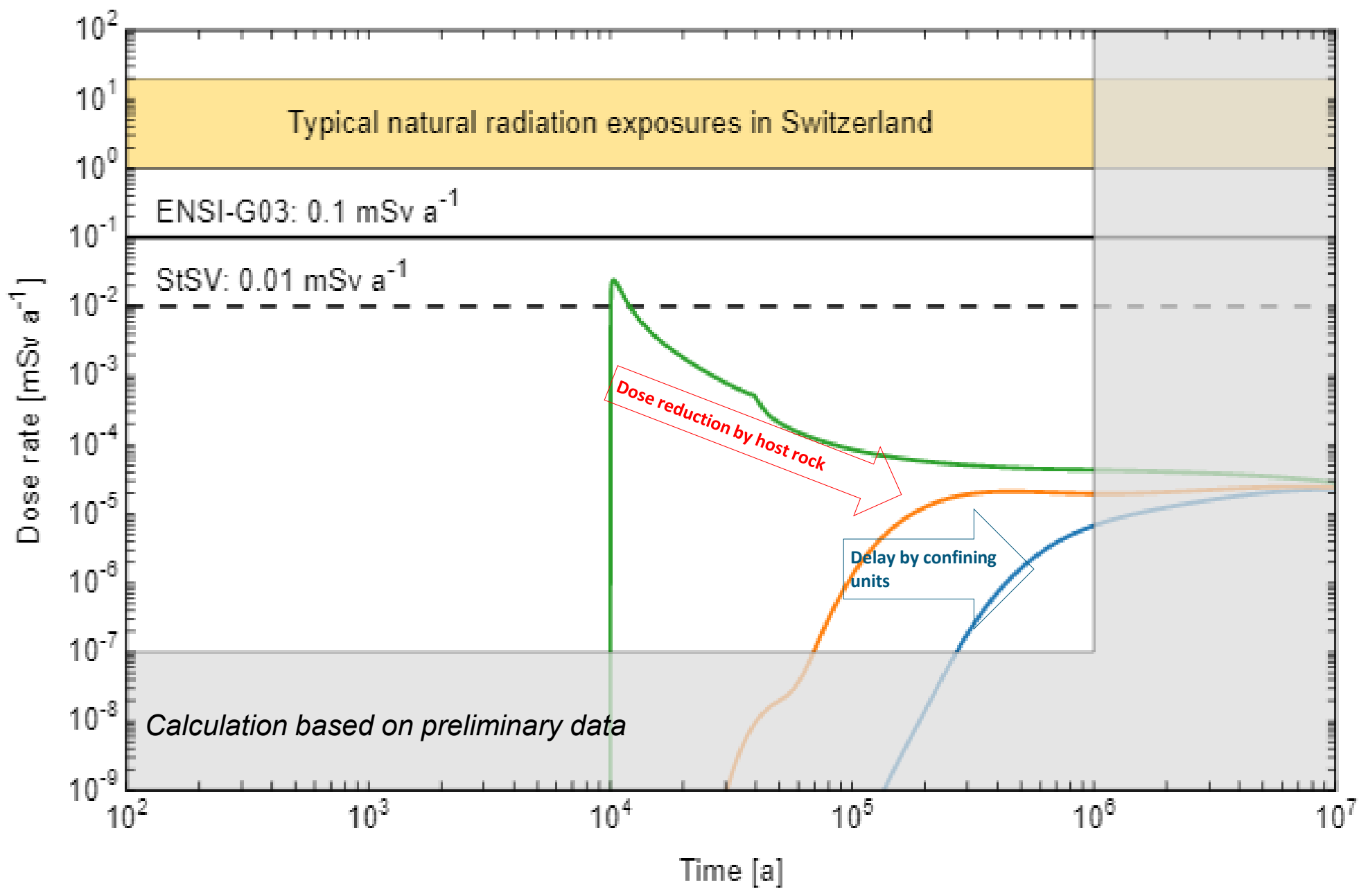

Near field

Geosphere: host rock

Geosphere: host rock \& confining units 


\section{Construction: revised rock testing methodology}

- Sample Conditioning

- CT scan allows variability assessment

- In-machine saturation / equilibration

- All triax-tests pore-pressure controlled

- multiple labs for cross checking

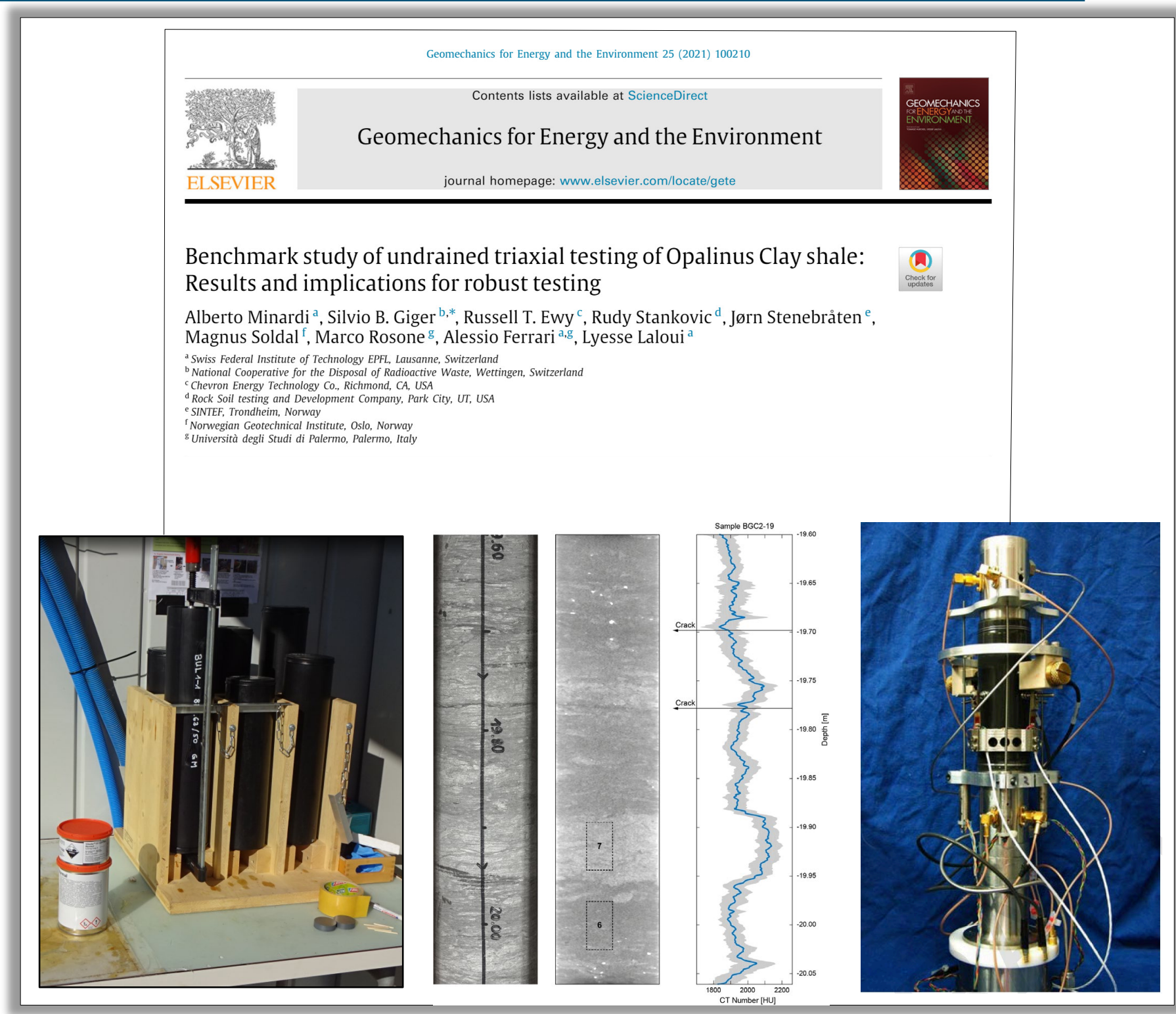




\section{Construction: core data to emplacement chamber design (crit. 4.1)}

- Rock testing results

- low variability

- Design calculations

- according to standard engineering methods

- key parameter: residual strength

- Effort for construction

- similar at all sites

- Repository at $\mathbf{9 0 0 ~} \mathrm{m}$ feasible

Rock testing results

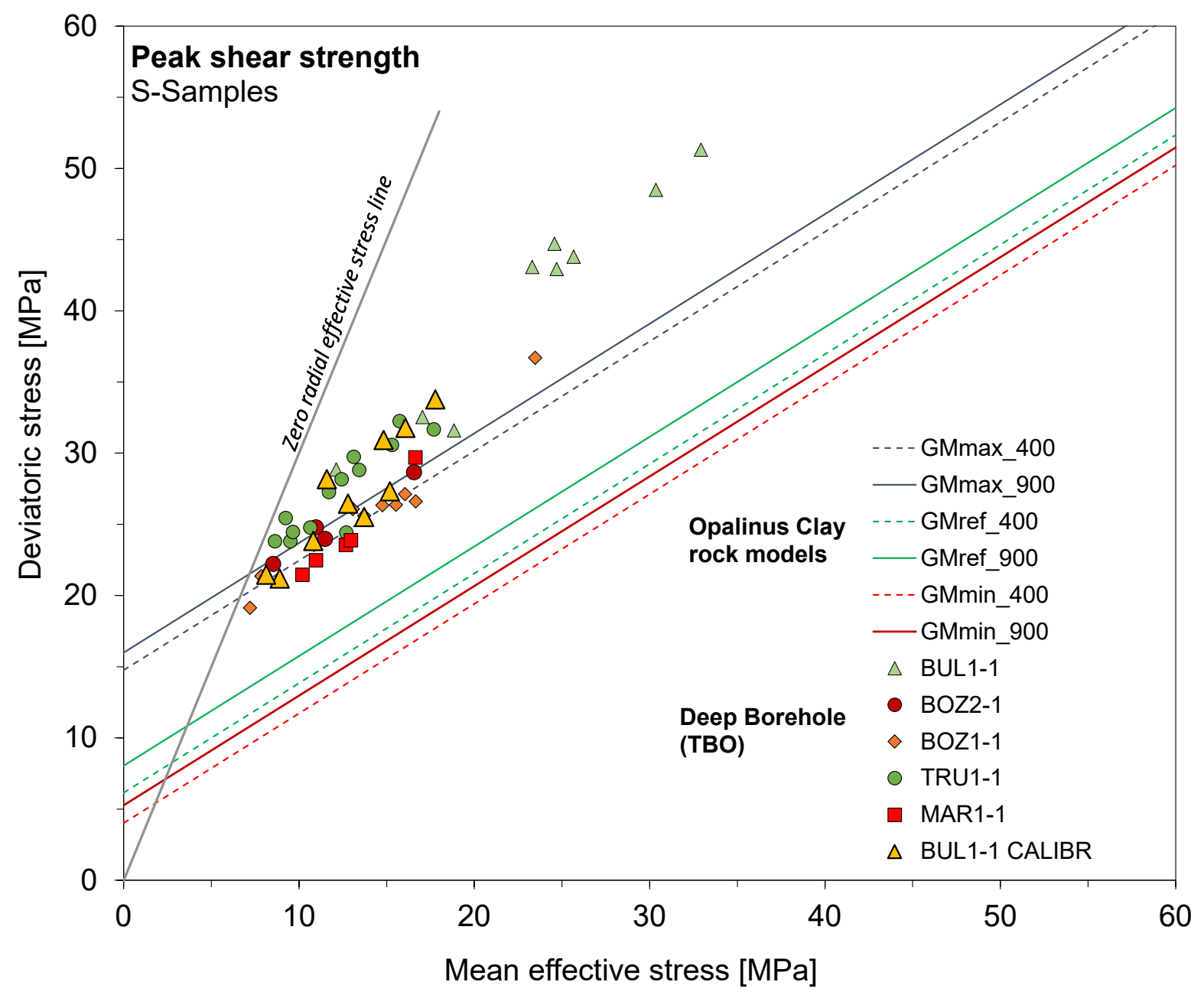




\section{Repository effects: gas transport (L/ILW case)}

- gas production in L/ILW

- mainly $\mathrm{H}_{2}$ from corrosion

- site conditions and properties from borehole samples and in-situ tests

- gas testing of faults

- model-based assessment

- adjust seal permeabilities to control gas pressure
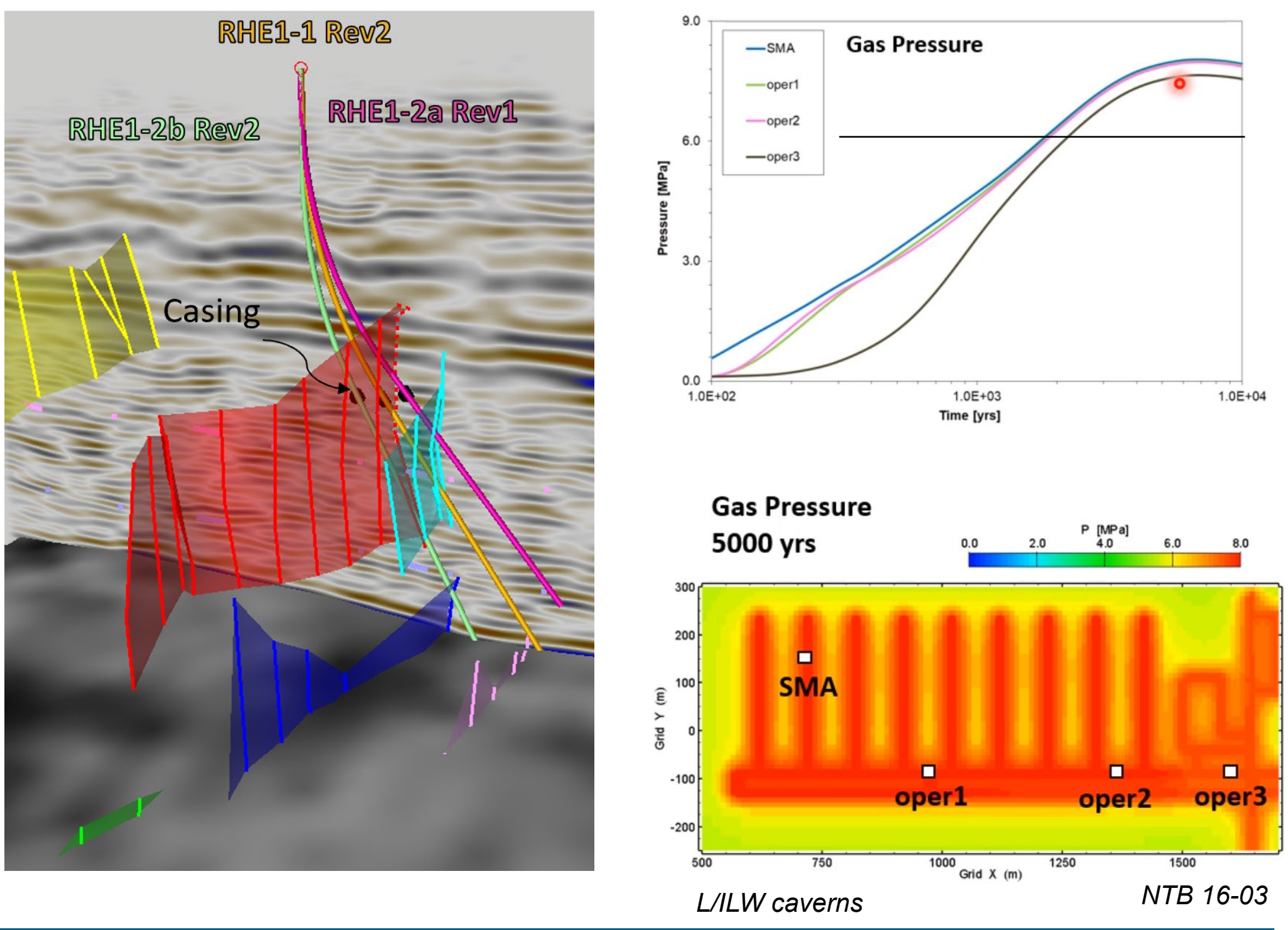


\section{Site selection for the best clay-hosted repository in Switzerland}

- Switzerland with similar site-selection strategy as Germany

- White Map

- Stepwise narrowing-in using technical / scientific criteria

- Safety driven only («best site»)

- Transparancy and participitation integrated from the start

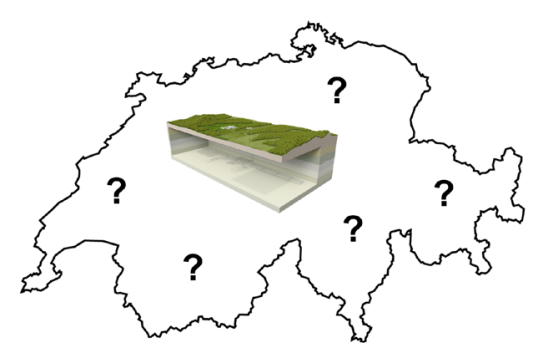

Criteria

1.1 Spatial extent

1.2 Hydraulic barrier effect

1.3 Geochemical conditions

1.4 Release pathways

2.1 Stability of the site and rock properties 2.2 Erosion

2.3 Repository-induced influences

2.4 Conflicts of use

- 2 of 3 steps in Switzerland completed

- 3 sites remaining. Similar and simple geology: Flat-lying sediments with 100 m thick clay layer

- Additional dose by repository far below regulatory limit in all regions

- 3rd step / «Etappe» ongoing

- Surface based exploration to feed site selection and safety case

- Aquisition of reliable high-quality data (undisputable decision basis)

- Seismic surveys: available space

- Cored boreholes: depth calibration of seismic data, properties

- Oct '22 announcement of site(s)

3.1 Ease of characterisation of the rock

3.2 Explorability of spatial conditions

3.3 Predictability of long-term changes

4.1 Rock mechanical properties and conditions

4.2 Underground access and drainage

\section{'24 general license application}

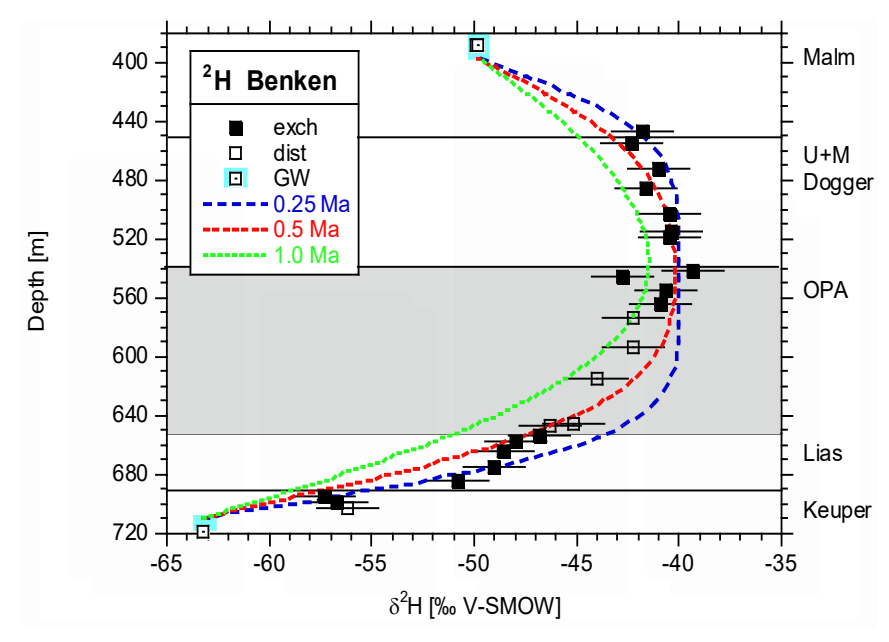

